UDC 378:373.3.091.12.011.3-051]:004(410) (043.5)

DOI: $10.24144 / 2524-0609.2018 .43 .63-66$

Harapko Vitaliia

Candidate of Pedagogical Sciences, Associate Professor

Associate Professor of the Department of English Philology and Teaching Methods of Foreign Languages

Mukachevo State University, Mukachevo, Ukraine

v.garapko@gmail.com

ORCID ID: https://orcid.org/0000-0001-7171-8448

Telychko Nataliia

Doctor of Pedagogical Sciences, Associate Professor

Associate Professor of the Department of English Philology and Teaching Methods of Foreign Languages

Mukachevo State University, Mukachevo, Ukraine

Natura.Carpaty@gmail.com

\title{
FEATURES OF DEVELOPING THE WORLDVIEW COMPETENCY OF FUTURE TEACHERS OF THE ENGLISH LANGUAGE AND FOREIGN LITERATURE
}

\begin{abstract}
In connection with modernisation processes taking place in the Ukrainian education and its transition to a competent paradigm, attention is paid to the competences and qualifications of education workers as they are to introduce new approaches to the development of education. Worldview competence is an element of educational competence that covers all three levels of competence development and is characterized by personal experience, values related to interaction with the environment. This competence implies planetary responsibility, noosphere thinking, a culture of civilisation, and a system of new values. The purpose of this article is to describe some of peculiarities of the process of developing the world-view competence of future teachers of English and foreign literature. The methods of research used: analysis and synthesis, comparison, systematisation and classification of philosophical, sociological, psychological and pedagogical scientific sources of literature in order to identify the theoretical foundations and the state of development of the problem under the study. The world-wide competence of a teacher of English and foreign literature is the competence in the world of thought associated with value orientations, the ability to see and understand the surrounding foreign world, to navigate within it, to realise its role and purposeful, creative orientation in the native and foreign language environment, the ability to choose target and meaningful parameters of teaching and learning process, making creative decisions.
\end{abstract}

Key words: world-view competence; general competence; educational competence; student's value orientations; micro-lesson; competency paradigm; competence approach.

Formulation of the problem. A competency paradigm is growing attention to competency and qualification characteristics of workers In connection with the modernization processes taking place in the Ukrainian foreign education and its transition to the European standards of education since they are intended to implement the new approaches to the development of education. Competency approach is the most productive for carrying out strategic tasks of educating a person of the society of the noosphere era (Спартин, 2003). Instead of a three-component model of the content of education in the current paradigm, these foundations are asked by a four-component model: knowledge, skills, an experience of the creative activity, experience of value relation (Данилова, 2001). Educational competencies are differentiated into three levels: key, general-subject and substantive. Worldview competency is an element of educational competency that covers all three levels and characterizes the experience of value-related attitude to the environment. This competency implies planetary responsibility, noospheric thinking, civilization culture and a system of new values. The basis of education is the high level of spirituality of man, which is impossible without the formation of tolerance to the «otherness»: thinking, faith, culture, systems of new values (Нечипорук, 2010). Noospheric thinking is a new stage in the development of the biosphere, a stage of mental control of relations between society and nature when a human activity becomes a force that directs development and nature.

Analysis of recent researches and publications. There have been partly reflected the requirements for the formation of a world-view competency of a student in the process of obtaining education in a higher educational establishments, such as: in the National State Program «Education (Ukraine XXI Century)» (1993), «The National Doctrine of the Development of Ukraine's
Education in the 21st Century» (2002), the Laws of Ukraine «On Education» (2016), «On Higher Education» (2014) «The Conception of National Education for Student Youth»(2009), the State Target Social Program «Youth of Ukraine» for 2016-2020 (2016).

A.O. Verbitsky offered a competent approach to learning in the concept of world-renowned competency is considered through a system of conscious knowledge: «in order to be theoretically and practically competent, the student needs to make a double transition: from the sign - to the thought, but from the thought - to the act, action. The transition from information to its use is mediated by the thought, which makes this information knowledge» (Krymskyi, 2010).

Consequently, this approach shapes the notion of professional competency as a system of knowledge and skills. V.O.Sukhomlinsky argued that the teacher should know and feel that, in his conscience, the fate of each child, and the mind, health, happiness of the person who is raised by the school depends on his spiritual culture and ideological wealth. Vasyl Olexandrovych considered the education of children sensitivity, kindness, a subtlety of feelings, the desire to bring joy to others, as well as the ability to counterbalance all negative goodness, attention to the person. An outstanding teacher came from his own conviction that the school should be in a beautiful natural environment, where many greenery, water, and if the vegetation around it is poor, then it is necessary to create its green protection at least in the immediate surroundings (Antonets, 2010).

Identification of previously unsettled parts of the problem. There came to adopt two vital conceptual models related to learning and cognition which they integrated together to create the organizational structure (and hence dynamic and disparate functions) of a critical learning system:

(1) An experiential model of learning developed by 
the American organizational psychologist David Kolb which portrayed learning as a perpetual cycle between the four cognitive activities that fluxed between the concrete and the abstract, and between reflection and action (Kolb, 1984).

(2) A three-level model of cognitive processing developed by another American researcher, Karen Kitchener that discriminated between cognition, metacognition and epistemic cognition (Kitchener, 1981). The integration of these two models together led to a framework for developing learning practices that focused in turn on:

(a) learning about the matter to hand and how to transform that for the better,

(b) learning about the learning processes that are brought to bear to learn about the matter to hand (metalearning), and how to improve them, and

(c) learning about the limitations to learning that are imposed by prevailing worldviews (epistemes) (epistemic learning), and how these can be appropriately characterized, challenged and, where indicated, transformed (Bawden, 2010).

The purpose of the article. The aim of this article is to describe some features of the process of developing the worldview competency of the future teachers of English language and foreign literature.

Methods of research. There has been involved the use of a system of research methods: theoretical methods: analysis and synthesis, comparison, systematization and classification of the provisions of philosophical, sociological, psychological and pedagogical scientific sources of literature in order to find out the theoretical foundations and state of development of the problem under study.

Presenting main material. Perhaps the most significant overall insight to emerge from this work in transformative development is captured by the following claim (Bawden, 2005): «Every systemic act of development in the material and social worlds demands the development of particular ways of «seeing» the world from a systems perspective along with a set of practical skills that reflect this particular systemic view of the world». At first sight, there would seem to be nothing particularly challenging about approaching matters from a perspective that appreciates the nature of wholeness and of the inter-connectedness of parts; or of a practice that continually places problems into their wider, more complex contexts as a key aspect of the problemsolving process. Nor would it seem to be that difficult, to approach changing problematic situations in such a manner that those changes would reflect an appreciation of the «whole picture», as it were, with respect to moral concerns as well as to the facts of the matter. We all know that each of us has certain moral principles and aesthetic ideals that we like to see played out in practice, just as we like to believe that we are rational in the ways that we come to decisions. "And yet in actuality, such systemic appreciation either of ourselves as integrated knowing valuing persons or of the world about us in all of its «big picture» complexity, is far from common in our society» (Bawden, 2010). Indeed it might be said that the prevailing approach to problem-solving and situation improving across the entire globe, remains very un-systemic even when the issues under review are messy and complex and the inadequacies of conventional problem-solving approaches are there for all to see.

«As it turns out, the ability to adopt a systems (or systemic) perspective to some issue or another in the «real» world, and to use systemic practices to achieve changes to it, are not at all a straightforward matter, of simply learning systems theories or learning to use systems methods in practice» (Bawden, 2005). Rather, the transformation of complex situations in the world in a systemic manner will only effectively happen if those who need to act to achieve those transformations are themselves transformed in the way that they 'see' that world and «act» in it. "This self-transformation involves challenges and changes to those profound sets of beliefs and values that constitute the perspectives that we each use to make sense out of the worlds about us. These are our worldviews, or our epistemes as Michel Foucault (Foucault, 1970) called them, from which word the notion of epistemic development is derived as an expression meaning the transformation of worldviews». This transformation of our abilities to view the world systemically and to act accordingly - the development of our systemic competencies as it were - is thus a function of our epistemic development (Bawden, 2005). This process involves profound changes to the beliefs that we hold about a whole lot of aspects to do with the world about us, as well as to the values that we cherish, that together constitute our intellectual and moral «sense-making» frameworks - also often referred to as paradigms.

It would appear that the essential reason for our intransigence in changing our prevailing ways of «seeing» and «doing», is fundamentally an expression of our prevailing unwillingness to even explore the character of the worldviews that we hold - as individuals and as whole cultures alike - to say nothing about our lack of preparedness to challenge and change them (Mankus, 2014). Worse yet, we are, by and large, all abysmally ignorant of the fact that we even hold to particular epistemes or worldviews, and accordingly assume specific intellectual, aesthetic, moral and even spiritual perspectives. Let alone are we aware of the specific characteristics of these worldviews or conscious of the extent to which they influence the way we live our lives.

It has long been accepted that what each of us «does» in (and to) the world about us in the course of our everyday lived experiences is a reflection of the way that, as individuals and members of particular cultures alike, we «see» or perceive that world. In other words, our everyday actions in our environments, in the broadest sense of that word, are greatly influenced by the particular mental models or worldview perspectives or mindsets or epistemes that we rely on, to help us make sense out of our day-to-day experiences of what we hold to be the reality about us as well as what we consider to be the right and proper things to be doing. It is our worldviews that act as the «filters» to our understandings, our frames of mind as the contexts for our judgments, our fundamental beliefs as the foundations for our morality (Bawden, 2010).

Importantly the worldviews that we hold, as individuals and as social collectives, can be transformed to a greater or lesser extent. «The so-called Enlightenment Movement of $17^{\text {th }} 18^{\text {th }}$ century Europe for instance, where reason trumped tradition, represents such epistemic transformation on a very grand sociocultural scale indeed»( Bawden, 2005). Other, much more modest transformations are represented by individuals «changing their own minds» about such matters as capital punishment, cigarette smoking, stem cell research, carbon emissions, animal welfare and a host of other epistemic positions that reflect changing beliefs and values. Such changes are often triggered by the arguments of others as well as by the sheer weight of previously ignored or newly generated evidence.

Given their significance, it is quite amazing that worldviews do not attract much attention from educators: 
"Most of the time we are not even aware that our behaviour is a reflection of a particular set of essentially tacit assumptions that each of us holds about the world about us, about the universe, and about our own human characteristics and how we relate to the world and to the greater universe beyond» (Bawden, 2010). Succinctly, worldviews - or Weltanschauungen to use the German expression which is commonly employed in the systems literature - can be seen to comprise a set of personal presuppositions about:

(a) the nature of foreign and native surroundings (or ontology, philosophically speaking),

(b) the nature and origins of the universe, of life itself and, especially, of the spiritual essence of mankind (or cosmology),

(c) the nature of knowledge (or epistemology) and

(d) the nature of human nature especially as it relates to motivations, dispositions and values, especially ethics and aesthetics (or axiology) (Bawden, 2010).

Conclusions and perspectives for further research. Interacting together, these constituencies of beliefs greatly shape our personal perceptions and, when reflective of our particular culture, our collective views of the world about us. They are thus the major determinants of the decisions and judgments that we make and the actions that we take. They play a major role in defining the goals that we set for ourselves as well as the goals that we believe we could set for ourselves, and indeed should set for ourselves as expressions of what we hold to be good or bad, right or wrong, virtuous or vicious.

Let us demonstrated the micro-lesson which shows by what means and forms the worldview competency can be involved in the studying process.

Micro-lesson. Topic: «Worldview competency as an active-procedural component of specialist training».

Aim: to define the meaning of the notion «a teacher's worldview competency» to practically apply means and forms of realization of worldview competency during studying English language and foreign literature.

The worldview competency of the teacher of English language and foreign literature is the competency in the world of thought, connected with value orientations, the ability to see and understand the surrounding foreign world, to navigate there, to realize its role and purposeful, creative orientation in the native and foreign language environment, the ability to choose the target and meaningful parameters of the process of teaching and learning, making creative decisions. The table 1 . shows the forms and means of implementing the worldview competency into the educational process of training of teachers of English language and foreign literature.

Table 1.

\begin{tabular}{|l|l|}
\hline \multicolumn{1}{|c|}{1. Forms } & \multicolumn{1}{|c|}{ 2. Means } \\
\hline Discussion. & $\begin{array}{l}\text { receptive-reproductive exercises (answer questions to the text that students have } \\
\text { listened to, choose the right answer to the questions before listening audio or watching } \\
\text { video) }\end{array}$ \\
\hline Group work. & reproductive exercises (write an essay) \\
\hline Interactive activities. & group exercises \\
\hline
\end{tabular}

\section{Список використаної літератури}

Антонець М.Я. Проблеми діяльності вчителя у педагогічній спадщчині Василя Сухомлинського: монографія. 3-те вид., доповн. К.: Четверта хвиля, 2010. 212 с.

Данилова В.С., Кожевников Н.Н. Планетарное мышление и его основные характеристики // Вестник Московского университета. Серия 7 «Философия». 2001. №3. С. 28-39.

Кримський С. Принцип духовності ХХІ століття // Директор школи. 2003. №8 (лютий). С. 4-5.

Манкусь I.B. Розвиток світоглядної компетентності майбутнього викладача [Електронний pecypc]. URL http://www. irbis-nbuv.gov.ua/.../cgiirbis_60.exe? (дата звернення: 15.09.2018)

Нечипорук Л.І. Формування ноосферної свідомості особистості як основи соціоприродної стабільності суспільства [Електронний ресурс]. URL http://www.irbis-nbuv.gov.ua/.../cgiirbis_64.exe? (дата звернення: 18.09.2018)

Спартин В. Ноосферная педагогика о формировании ноосферного менталитета // Родительское собрание. 2003. C. $65-70$.

Bawden, R.J. Systemic Development at Hawkesbury: Some personal lessons from experience. Systems Research and Behavioural Science 22. 2005. pp.151-164

Bawden R.J. Messy issues, Worldviews and systemic competencies.Chapter 6 / In C.P.Blackmore (ed). Social learning systems and communities of practice. London: Springer. 2010. pp.89-102.

Foucault M. The Order of Things: An Archaeology of the Human Sciences. Pantheon: New York. 1970. 28p.

Kitchener K.S. Cognition, metacognition, and epistemic cognition: A three level model of cognitive processing. Human Development 26. 1983. pp.222-232

Kolb D.A. Experiential Learning: Experience as the Source of Learning and Development. Englewood Cliffs, NJ: PrenticeHall. 1984. 18 p.

\section{References}

Antonets, M. Ya.(2010) Problemy diialnosti vchytelia u pedahohichnii spadshchyni Vasylia Sukhomlynskoho: monohrafiia [Problems of the teacher's activity in the pedagogical heritage of Vasyl Sukhomlynsky]. K.: Chetverta khvylia [in Ukrainian]. Bawden, R.J. (2005) Systemic Development at Hawkesbury: Some personal lessons from experience. Systems Research and Behavioural Science, 22, 151-164.

Bawden, R.J. (2010). Messy issues, Worldviews and systemic competencies. Chapter 6. p.89-102 / In C.P.Blackmore (ed). Social learning systems and communities of practice. London: Springer.

Danylova, B.C. (2001). Planetarnoe mishlenye y eho osnovnie kharakterystyky [Planetary thinking and its main characteristics]. Bulletin of the Moscow University. Series Phylosophy, 3, 28-39 [in Russian].

Foucault, M. (1970). The Order of Things: An Archaeology of the Human Sciences. Pantheon: New York.

Kitchener, K.S. (1983). Cognition, metacognition, and epistemic cognition: A three level model of cognitive processing. Human Development, 26, 222-232.

Kolb, D.A. (1984). Experiential Learning: Experience as the Source of Learning and Development. Englewood Cliffs, NJ: Prentice-Hall.

Krymskyi, S. (2003). Pryntsyp dukhovnosti XXI stolittia [Principle of spirituality of the XXI century]. Dyrektor shkolu, 8 (february), 4-5. [in Ukrainian]. 
Mankus, I.V. (2014). Rozvytok svitohliadnoi kompetentnosti maibutnoho vykladacha [Development of worldview competence of the future teacher]. URL http://www.irbis-nbuv.gov.ua/.../cgiirbis_60.exe? (access date: 15.09.2018) [in Ukrainian].

Nechyporuk, L.I.(2010). Formuvannia noosfernoi svidomosti osobystosti yak osnovy sotsiopryrodnoi stabilnosti suspilstva [Formation of the noosphere consciousness of the individual as the basis of socio-natural stability of society]Rivne URL http:// www.irbis-nbuv.gov.ua/.../cgiirbis_64.exe? (access date: 18.09.2018)

Spartyn, V. (2003). Noosfernaia pedahohyka of formyrovanyy noosfernoho mentalyteta [Noospheric pedagogy on the formation of a noosphere mentality] Parental Assembly, 4, 65-70. [in Russian].

Стаття надійшла до редакції 05.10.2018 р. Стаття прийнята до друку 10.10.2018 р.

Гарапко Виталия

кандидат педагогических наук, доцент

доцент кафедры английской филологии и методов обучения иностранным языкам Мукачевский государственный университет, г.Мукачево, Украина

Теличко Наталия

доктор педагогических наук, доцент

доцент кафедры английской филологии и методов обучения иностранным языкам

Мукачевский государственный университет, г.Мукачево, Украина

\section{ОСОБЕННОСТИ РАЗВИТИЯ МИРОВОЗЗРЕНЧЕСКОЙ КОМПЕТЕНТНОСТИ БУДУЩИХ УЧИТЕЛЕЙ АНГЛИЙСКОГО ЯЗЫКА И ИНОСТРАННОЙ ЛИТЕРАТУРЫ}

Аннотация. Мировоззренческая компетенция является элементом образовательной компетенции, охватывающей все три уровня компетентностного развития и характеризуется личным опытом, ценностями, связанными с взаимодействием с окружающей средой. Эта компетентность предполагает планетарную ответственность, ноосферное мышление, культуру цивилизации и систему новых ценностей. Цель этой статьи - описать некоторые особенности процесса развития мировоззренческой компетентности будущих учителей английского языка и зарубежной литературы. Нами применены теоретические методы: анализ и синтез, сравнение, систематизация и классификация положений философских, социологических, психологических и педагогических научных источников литературы с целью выявления теоретических основ и состояние развития исследуемой проблемы. Мировоззренческая компетенция учителя английского языка и зарубежной литературы - компетентность в мире мысли, связанная с ценностными ориентациями, умением видеть и понимать окружающий иностранный мир, ориентироваться в нем, осознать свою роль и целевое, креативное ориентирования в родном и иностранном языковом окружении, возможность выбирать целевые и содержательные параметры процесса преподавания и обучения, принятия творческих решений.

Ключевые слова: мировоззренческая компетентность; общие компетентности; образовательная компетентность; ценностные ориентации студента; микро-урок; компетентностная парадигма; компетентностный подход.

Гарапко Віталія Іванівна

кандидат педагогічних наук, доцент

доцент кафедри англійської філології та методів навчання іноземним мовам Мукачівський державний університет, м.Мукачево, Україна

Теличко Наталія Вікторівна

доктор педагогічних наук, доцент

доцент кафедри англійської філології та методів навчання іноземним мовам Мукачівський державний університет, м.Мукачево, Україна

\section{ОСОБЛИВОСТІ РОЗВИТКУ СВІТОГЛЯДНОЇ КОМПЕТЕНТНОСТІ МАЙБУТНІХ ВЧИТЕЛІВ} АНГЛІЙСЬКОЇ МОВИ ТА ІНОЗЕМНОЇ ЛІТЕРАТУРИ

Анотація. У зв'язку з процесами модернізації, що відбуваються в українській освіті та їі переходом до компетентісної парадигми зростає увага до компетенцій та кваліфікаційних характеристик працівників освіти, оскільки вони призначені для впровадження нових підходів у розвиток освіти. Світоглядна компетенція $\epsilon$ елементом освітньої компетенції, що охоплює всі три рівні компетентнісного розвитку та характеризується особистим досвідом, цінностями, пов'язаними із взаємодією з навколишнім середовищем. Ця компетентність передбачає планетарну відповідальність, ноосферне мислення, культуру цивілізації та систему нових цінностей. Мета цієї статті - описати деякі особливості процесу розвитку світоглядної компетентності майбутніх вчителів англійської мови та зарубіжної літератури. Нами застосовано теоретичні методи: аналіз та синтез, порівняння, систематизація та класифікація положень філософських, соціологічних, психологічних та педагогічних наукових джерел літератури з метою виявлення теоретичних засади і стан розвитку досліджуваної проблеми. Світоглядна компетенція вчителя англійської мови та зарубіжної літератури - компетентність у світі думки, пов'язана $з$ ціннісними орієнтаціями, вмінням бачити та розуміти навколишній іноземний світ, орієнтуватися в ньому, усвідомити свою роль і цільове, креативне орієнтування в рідному та іноземному мовному оточенні, можливість вибирати цільові та змістовні параметри процесу викладання та навчання, прийняття творчих рішень.

Ключові слова: світоглядна компетентність; загальні компетентності; освітня компетентність; ціннісні орієнтації студента; мікро-урок; компетентнісна парадигма; компетентнісний підхід. 